Meta

Journal des traducteurs

Translators' Journal

\title{
Emphatic Italics in English Translations: Stylistic Failure or Motivated Stylistic Resources?
}

\section{Gabriela Saldanha}

Volume 56, numéro 2, juin 2011

Les corpus et la recherche en terminologie et en traductologie Corpora and Research in Terminology and Translation Studies

URI : https://id.erudit.org/iderudit/1006185ar

DOI : https://doi.org/10.7202/1006185ar

Aller au sommaire du numéro

Éditeur(s)

Les Presses de l’Université de Montréal

ISSN

0026-0452 (imprimé)

1492-1421 (numérique)

Découvrir la revue

Citer cet article

Saldanha, G. (2011). Emphatic Italics in English Translations: Stylistic Failure or Motivated Stylistic Resources? Meta, 56(2), 424-442.

https://doi.org/10.7202/1006185ar

\section{Résumé de l'article}

Dans le présent article, nous montrons que l'italique emphatique, un procédé typographique négligé par les linguistes qui la considèrent comme une faiblesse de style, remplit au contraire une fonction stylistique importante en anglais. L'italique évoque implicitement les structures prosodiques de l'oral en rapport avec un focus informationnel. Elle joue ainsi un rôle crucial de structuration de l'information et confère aux textes écrits certaines valeurs expressives inhérentes à l'oral. L'italique emphatique est plus courante en langue anglaise que dans d'autres langues, car si la première utilise

l'accentuation tonique pour marquer un focus informationnel, les autres font plutôt appel à des procédés purement linguistiques jouant sur la syntaxe. Ces considérations soulèvent la question de la traduction depuis ou vers l'anglais. La présente étude fait état d'une analyse de données provenant d'un corpus bidirectionnel anglais-portugais (COMPARA), qui semblent indiquer que le recours à l'italique est moins courant dans les textes anglais traduits du portugais que dans les textes rédigés en anglais. Cette tendance pourrait s'expliquer par des caractéristiques communes à tous les textes traduits, notamment l'explicitation et la normalisation (" conventionalisme "). Un examen plus approfondi de traductions individuelles révèle cependant l'usage de l'italique est inconstant et que le choix de l'utiliser ou non refléterait plutôt le profil stylistique propre à chaque traducteur.
Ce document est protégé par la loi sur le droit d'auteur. L'utilisation des services d'Érudit (y compris la reproduction) est assujettie à sa politique d'utilisation que vous pouvez consulter en ligne.

https://apropos.erudit.org/fr/usagers/politique-dutilisation/ 


\title{
Emphatic Italics in English Translations: Stylistic Failure or Motivated Stylistic Resources?
}

\author{
GABRIELA SALDANHA \\ University of Birmingham, Birmingham, $U K$ \\ g.saldanha@bham.ac.uk
}

\begin{abstract}
RÉSUMÉ
Dans le présent article, nous montrons que l'italique emphatique, un procédé typographique négligé par les linguistes qui la considèrent comme une faiblesse de style, remplit au contraire une fonction stylistique importante en anglais. L'italique évoque implicitement les structures prosodiques de l'oral en rapport avec un focus informationnel. Elle joue ainsi un rôle crucial de structuration de l'information et confère aux textes écrits certaines valeurs expressives inhérentes à l'oral. L'italique emphatique est plus courante en langue anglaise que dans d'autres langues, car si la première utilise l'accentuation tonique pour marquer un focus informationnel, les autres font plutôt appel à des procédés purement linguistiques jouant sur la syntaxe. Ces considérations soulèvent la question de la traduction depuis ou vers l'anglais. La présente étude fait état d'une analyse de données provenant d'un corpus bidirectionnel anglais-portugais (COMPARA), qui semblent indiquer que le recours à l'italique est moins courant dans les textes anglais traduits du portugais que dans les textes rédigés en anglais. Cette tendance pourrait s'expliquer par des caractéristiques communes à tous les textes traduits, notamment l'explicitation et la normalisation («conventionalisme»). Un examen plus approfondi de traductions individuelles révèle cependant l'usage de l'italique est inconstant et que le choix de l'utiliser ou non refléterait plutôt le profil stylistique propre à chaque traducteur.
\end{abstract}

\section{ABSTRACT}

This article argues that emphatic italics, a typographic feature regularly ignored by linguists and associated with poor style, have an important stylistic function in English, often working in implicit association with prosodic patterns in spoken language to signal marked information focus, thus fulfilling an important role in information structure and adding a conversational and involved tone to written texts. Emphatic italics are more common in English than in other languages because tonic prominence is the preferred means of marking information focus in English, while other languages use purely linguistic devices, such as word order. Thus arises the question of what happens in English translations from and into other languages. The study presented here looks at results obtained from a bidirectional English-Portuguese corpus (COMPARA) which suggest that italics may be less common in English translations from Portuguese than in non-translated English texts. This trend could potentially be explained by the use of common features of translated language, in particular explicitation and conservatism (also known as normalization). However, a closer look at the work of particular translators shows that the avoidance or use of italics is not a consistent feature of translations and may be a characteristic feature of the stylistic profile of certain translators.

\section{MOTS-CLÉS/KEYWORDS}

italique emphatique, focus informationnel, style du traducteur, corpus, portugais-anglais, espagnol-anglais

emphatic italics, information focus, translator style, corpora, Portuguese-English, Spanish-English 


\section{Why italics?}

In recent years experts in the fields of typography and applied linguistics have started to explore the links between the two disciplines (Crystal 1998; Walker 2001). However, academic work in this area is still scarce. In translation studies, the work of Schopp $(1996 ; 2002)$ has called attention to the relevance of typographical knowledge for translators. A text's visual organisation has an impact on how it is understood and interpreted by readers, possibly facilitating readability or highlighting some information at the expense of other information. Font size, layout, colour and print quality in bilingual texts can be indicative of the status of the different languages represented (Walker 2001). The impact is more clearly seen in certain types of texts, a typical example being advertising material. In the literary narrative genre, on the other hand, typesetting rules are stricter and more conventional; italics and quotation marks are among the limited extra-linguistic devices that call the reader's attention to particular forms, and they are also two devices over which control relies, at least to some extent, on the text's originator (author/translator), rather than its producer (typesetter).

It has been suggested that Romance and Germanic typographic cultures may have different preferences as to the use of italics (Schopp, personal communication). Therefore, when looking at translations, it is important to note where the conventions differ from one language to another or where contradictory traditions co-exist in a single language. This can help us determine whether the use of italics in the target texts can be explained as the result of different typographical conventions, or whether it marks a more meaningful intervention on the part of the translator. In the absence of academic work in contrastive typography, an alternative source of information is style guides: typography has had a long-standing prescriptive tradition, where style manuals have held considerable authority (Walker 2001: 87). However, a comparative study of recommendations for the use of italics in English, Spanish and Portuguese stylistic reference works carried out by Saldanha (2005) shows that guides are notoriously vague about emphatic italics. Although most guides mention italics for emphasis (see also Walker 2001: 100), they are generally vague about what is meant by emphasis. One Spanish guide groups emphatic italics together with italics used to highlight non-literal meanings, ${ }^{1}$ and another fails to distinguish emphatic italics from italics highlighting words that are mentioned rather than used (Martins 2003) - such as emphasis in the previous sentence. Both functions differ from that performed in English by emphatic italics, where they generally mark tonic prominence in written language.

To our knowledge, no descriptive studies (cross-linguistic or of any other kind) on the use of italics in translation, with the exception of Slancarova (1998), López Folgado (2000) and Douglas (2009), have been done. López Folgado (2000) focuses on italics in translations from English into Spanish. He distinguishes between italics conveying pragmatic implicatures which either signals contrastive focus or highlights enriched lexical terms, and he draws from a range of sources for his examples. He concludes that they are not coherently employed by authors nor translators "who do not often see why such an ostensive device is in fact needed" (López Folgado 2000: 96).

Slancarova (1998) compares the use of italics in English and Czech, and her classification is based on the use of italics prescribed by different style guides and on 
evidence from her corpora. Based on an analysis of four Czech novels, three English novels, and Czech translations of the latter, she argues that italics are an important stylistic means in English fiction while they seem to play a less important role in Czech writing. With respect to the English-Czech translations, she concludes that despite a clear influence of the source text on the use of italics in the translations, translators are not consistent. A wide range of different strategies does seem to be adopted by each translator. This paper supports Slancarova's argument that italics are an important stylistic tool in English fiction, while they seem to play a less important role in other languages (in this case Spanish and Portuguese).

Douglas (2009) presents a very similar argument to the one developed here and in Saldanha (2005) in terms of the communicative function of italics in English. He uses a bidirectional parallel corpus consisting of English and Italian texts to explore the use of italics in the two languages and the way they are translated. Of particular interest are the results that show a relatively low incidence of italics denoting tonic prominence in the Italian source texts (9.6\% of all occurrences), which is in sharp contrast to the extremely high occurrence of italics communicating tonic prominence in the English source texts (86.3\% of all occurrences). Italicized items highlighting tonic prominence in the English texts tend to be one-syllable functional words, particularly personal pronouns and auxiliary verbs. These items do not necessarily have equivalent items in Italian, a more highly inflected language than English. Douglas, like Slancarova and López Folgado, demonstrates that translators working from English use a wide range of strategies to convey prominence without resorting to italics. Interestingly, the results presented in this paper show that translators working into English can use this resource in a rather consistent and highly distinctive manner.

\section{The communicative function of emphatic italics in English: marking information focus}

As mentioned above, style guides are very vague in their description of how emphatic italics should be used and they often associate italics with poor style. Consequently, one must ask if they are really necessary? In her 'Zero Tolerance' guide to punctuation, Truss (2003: 145) asks: "Of all the conventions of print that make no objective sense, the use of italics is the one that puzzles most. How does it work?" Truss does not give a detailed account of when, where nor how italics are to be used, but warns readers that

[1]ike the exclamation mark, however, italics should be used sparingly for the purposes of emphasis - partly because they are a confession of stylistic failure, and partly because readers glancing at a page of type might unconsciously clock the italicised bit before starting their proper work of beginning in the top left-hand corner (Truss 2003: 147).

Fowler (1965: 313) describes them as "a primitive way of soliciting attention" and expects the "practised writer" to know that "it is an insult to the reader's intelligence to admonish him periodically by a change of type that he must now be on the alert." However, he also recognizes that sometimes "italics have definite work to do when a word or two are so printed," and he lists cases where italics may be saying to the reader: 
a) This word, and not the whole phrase of which it forms part, contains the point;

b) This word is in sharp contrast to the one you may be expecting;

c) These two words are in sharp contrast;

d) If the sentence were being spoken, there would be a stress on this word;

e) This word wants thinking over to yield its full content.

(Fowler 1965: 313)

Fowler's work was probably one of the first attempts to describe in detail the communicative function of emphatic italics and his work is still, to the best of our knowledge, the only English style guide that addresses the issue. The latest edition of Fowler's Modern English edited by Burchfield (1996) is no exception.

The first thing to point out as to the function of emphatic italics is - as noted by McAteer (1990) and López Folgado (2000) among others - that they facilitate understanding and the interpretation of the intended meaning. McAteer (1990), in a study that compares readers' interpretations of passages where italics and capitals are sometimes used and sometimes not, demonstrates that italics can actually lead readers to adopt one of two possible and valid interpretations. However, a Systemic Functional Grammar approach to the function of emphatic italics suggests that it considerably more complex than that. The physical salience of a word signals its informational salience and therefore it can be used to signal a marked information structure.

Information structure is understood here according to Halliday (1967). Given information represents the common ground between speaker and hearer and acts as a reference point to which the new information can be related. In an unmarked information structure, given information precedes new information. Within each information unit, a certain element or elements are selected as points of prominence within the message. This is the information focus or foci. The focal point is new information, in the sense that the speaker presents it as not being recoverable from the preceding discourse. This does not necessarily mean that it has not been previously mentioned (Halliday 1967: 204); the focal information may be a feature of mood rather than cognitive content, such as when a speaker confirms an asserted proposition (see example 1c below), or it may be a matter of contrast with what has been said before or what might be expected (see examples 1b and 2) (Halliday 1967: 206).

Halliday argues that information structure in English is achieved through intonation patterns. In the unmarked structure, each information unit is a clause, but clause and information unit are not necessarily co-extensive. The information unit is actually a phonological unit, realized by (and co-extensive with) the tone group, with the tonic accent - what we usually perceive as stress - falling on the new information. In unmarked structures, the tonic falls on the final accented lexical item of a tone group. When the tonic falls elsewhere, the focus becomes marked. In example 1a (which is hypothetical), if the information focus is unmarked, the tonic accent will fall on the first syllable of listened. If the stress is placed elsewhere in the utterance, the information focus becomes marked, as in examples $1 \mathrm{~b}$ and $1 \mathrm{c}$ (the symbol // marks the boundary of a tonic unit and the tonic accent is underlined when the focus is marked):

(1) a. //he has listened//

b. //he has listened//

c. //he has listened// 
Different grammars describe information structure and information focus in fairly different terms (see Butler 2005 for a comparison of how Functional Grammar, Role and Reference Grammar and Systemic Functional Grammar account for information focus), and some recognize syntactical and morphological means of identifying new and given information. However, it is generally agreed that the preferred way of signalling information focus in English is through prosody. The essentially prosodic (as opposed to syntactic or lexical) nature of the information system in English may explain why sometimes a typographical feature, namely italics, is used in order to mark information focus (see also Norrick 2000 on the role of italics in encoding intonation).

Example 2, taken from an English translation of a Spanish text, puts the hypothetical example provided above in a real context, and shows that the italics perform their emphatic function through association with the prosodic patterns of English. In other words, they reproduce in written form the tonic accent that is used in spoken English to mark information focus: ${ }^{2}$

(2) That's why he warns her to listen to what her body is telling her.

"As I think I mentioned before, the body is governed by very idiosyncratic rules." It's clear that he has listened to her body, through the stethoscope that is.

(Valenzuela 1993; translated by Jull Costa 1995)

In spoken discourse, we sometimes place extra stress on the tonic segment. Likewise, in writing, the focus is sometimes italicized despite being the last accented lexical item in a clause. Whenever italics are used to signal information focus, this can be considered marked, since the default or unmarked realisation would be nonitalicized.

\section{Information focus across languages}

Focus is marked differently according to the language involved. With regard to French/English translation, Hervey and Higgins (2002: 107) suggest that "what is expressed in French through sequential focus, perhaps in combination with illocutionary particles, is often most idiomatically expressed in English through voice stress and intonation alone." This is also valid for other Romance languages. Example 3, which provides the source text for example 2, clearly shows that italics in English compensate for the focus which is marked by an illocutionary particle in Spanish:

(3) Se ve que él sí ha escuchado, a través del estetoscopio se entiende. [It can be seen that he yes has listened, through the esthetoscope it is understood.] It's clear that he has listened to her body, through the stethoscope that is.

(Valenzuela 1993; translated by Jull Costa 1995)

Generally speaking, while some languages, such as Dutch and English, use prosodic means to mark information focus, other languages, such as those of the Romance family, tend to rely heavily on word order (see, for example, Swerts, Krahmer et al. 2002, Vallduví and Engdahl 1996; Martínez Caro 1999; Cruttenden 1997). Martínez Caro $(1995 ; 1999)$ argues that the relative free word order in some languages is to a great extent motivated by pragmatic and discourse factors, among which the marking of information focus play an important role. In example 4, information focus is marked in Portuguese using a post-verbal subject (the non-marked 
word order would have been subject - verb - object). The translator reflects the marked constituent order in the source text by using an identifying clause in English, but also highlights the subject of the main clause using italics: ${ }^{3}$

(4) Preto era ele.

[Black was he.]

Black was what he was.

(Dourado 1975; translated by Parker 1988)

\section{Emphatic italics in English and Portuguese - a corpus-based perspective}

It has been suggested that, in English, emphatic italics have a clear and important function - marking information focus through its association with prosodic patterns - which cannot be easily fulfilled by linguistic choices alone. This leads to the expectation that italics, despite their weak stylistic image in style guides, are considerably more frequent in written English than in languages where information focus can be conveyed through linguistic means, such as word order. The results presented by Slancarova (1998) and Douglas (2009) support this hypothesis in relation to Czech and Italian respectively. A search for emphatic italics in COMPARA, ${ }^{4}$ a bi-directional parallel corpus of Portuguese and English narrative (Frankenberg-Garcia and Santos 2003), suggests that this is also the case for this particular language pair (see Table 1).

TABLE 1

Emphatic italics in non-translated English and Portuguese texts in COMPARA

\begin{tabular}{|l|c|c|}
\hline & $\begin{array}{c}\text { Non-translated } \\
\text { English texts }\end{array}$ & $\begin{array}{c}\text { Non-translated } \\
\text { Portuguese texts }\end{array}$ \\
\hline Total number of words & 502,337 & 388,452 \\
\hline Total number of texts & 21 & 28 \\
\hline Texts with emphatic italics & 19 & 18 \\
\hline Total number of emphatic italics & 561 & 119 \\
\hline
\end{tabular}

In the English sub-corpus, almost all texts (90\%) include italics. The text with the highest number of occurrences (133, i.e. $23.7 \%$ of all italicized lexical items in the sub-corpus) is Through the Looking Glass, by Lewis Carroll. The second one is $A$ Spanish Lover, by Joanna Trollope (with 72 occurrences of italics). Both texts equally stand out from the others for several reasons. Through the Looking Glass is a classic of children's literature whose genre has been described variously as fantasy, nonsense and fairy tale. Trollope is probably one of the few writers of popular literature and romance included among non-translated English texts in COMPARA.

In the Portuguese corpus, $64 \%$ of all the texts include italics and the distribution of italics between texts is highly skewed: one text by Mário de Sá-Carneiro (A grande sombra) accounts for most of the occurrences found in the corpus (78 occurrences, or $65.5 \%$ ). The use of italics is actually a well-known peculiarity of this $19^{\text {th }}$-century Portuguese writer. The two texts with the second highest use of italics, with 9 occurrences each, include another text by the same author, A confissão de Lúcio, and a text by Jorge de Sena, Sinais de Fogo. In the English sub-corpus, on the other hand, 16 of the 19 texts with emphatic italics have more than 10 occurrences, the average number of italicized items per text being 26.7. 
The Portuguese sub-corpus differs from the English sub-corpus not only in terms of frequency and consistency in the use of emphatic italics, but also in terms of the type of emphatic italics used. Emphatic italics in the English sub-corpus, with a few exceptions (see section 6.2, example 7), mark information focus; but this is clearly not the case in the Portuguese sub-corpus. Information focus does not usually extend over more than one lexical item because it necessarily implies de-accenting the rest of the tone group, with the only exception being cases where there is a secondary focus (Haliday 1967). Besides, in English, italics are more commonly used when the information focus is on functional words, which are generally non-accented. Douglas (2009) reports that only 15\% of the italicized items in his English corpus is lexical words.

In the Portuguese sub-corpus, emphatic italics generally highlight longer units, in some cases whole clauses, as in example 5 below from a text by Mário de Sá-Carneiro. It would certainly be interesting to analyze in more detail the communicative function of italics in these cases, but for reasons of space this paper will concentrate on the focus-marking function of italics in English texts and their translations.

(5) [...] ainda hoje não perdi o medo do que pode haver para lá de um reposteiro [...]

[...] I have not lost that fear of what might lie behind a curtain, [...]

(de Sá-Carneiro 1914; translated by Jull Costa 2000)

\section{Emphatic italics in translated texts: evidence of features of translation or stylistic preferences?}

This section reports results from a study that looks at the use of italics in English translations of Portuguese texts. The results are used as a point of reference for another study that compares how two translators, Margaret Jull Costa and Peter Bush, use italics in their English translations of Spanish and Portuguese texts. Before presenting those results, however, it is interesting to note, as a methodological exercise, that if we were to follow the current literature on features of translation (also known under the more controversial title of translation universals) we would arrive at contradictory predictions regarding the use of italics in translated English.

As mentioned above, italics have been shown to facilitate the understanding and interpretation of the intended meaning (McAteer 1990; López Folgado 2000). Facilitating understanding is a tendency commonly attributed to translators. This observation is the cornerstone of the explicitation hypothesis that was put forward as a potential translation universal (Baker 1993; 1995). The explicitation hypothesis suggests that translators tend to spell things out and facilitate interpretation. This would lead to the expectation that new information would be more frequently marked by emphatic italics in translated texts than in non-translated texts.

Another reportedly common feature of translation is conservatism: compared to non-translated texts, translations tend towards textual conventionality, favouring those uses that are clearly sanctioned by the target text conventions (Vanderauwera 1985: 93; Baker 1996: 176-177). Given the bad stylistic image that emphatic italics receive in style guides, translators would then be expected to avoid them more than other types of writers. This is contrary to what the explicitation hypothesis predicts.

According to the unique items hypothesis, those linguistic features that do not have similarly manifested linguistic counterparts in the source language will be 
under-represented in the target text, for the simple reason that they do not readily appear as translation equivalents (Tirkkonen-Condit 2004: 177-178). Strictly speaking, this hypothesis cannot be applied to the use of italics because emphatic italics are not unique to English. However, it has been noted that italics are considerably less common and not used for the same purposes in Romance languages. Therefore, following the same logic underlying the unique item hypothesis, we would predict that italics marking information focus in translated English will be less frequent than in non-translated English when the source languages are Spanish and Portuguese. This prediction is in line with the one based on the conservatism hypothesis, but not with the one based on the explicitation hypothesis.

TABLE 2

Emphatic italics in non-translated English text and in translations from Portuguese to English

\begin{tabular}{|l|c|c|}
\hline & \multicolumn{2}{|c|}{ COMPARA } \\
\hline & Non-translated Texts & Translated texts \\
\hline Number of words in corpus & 502,337 & 516,743 \\
\hline Number of texts in corpus & 21 & 29 \\
\hline Average number of words per text & 23,920 & 17,819 \\
\hline Texts with emphatic italics & 19 & 12 \\
\hline Total emphatic italics & 561 & 57 \\
\hline Normalised emphatic italics per $\mathbf{3 0 , 0 0 0}$ words $^{\mathbf{5}}$ & 33.5 & 3.3 \\
\hline
\end{tabular}

The results from COMPARA reported above (Table 2) show that emphatic italics in fictional texts translated from Portuguese into English are considerably less frequent than in non-translated English texts. Interestingly enough, the results from a smaller corpus of two English texts and two translations from Italian into English (Douglas 2009) point in the same direction. However, without further research into the translators' motivations, it is not possible to determine whether this is a reflection of their conservative tendencies or a confirmation of the 'rare items hypothesis' suggested above, or indeed, of any of these possibilities. Although the overall number of italics in translated texts is lower than in non-translated texts, this result averages out widely differing tendencies across translators: while some translators consistently avoid using emphatic italics, others use them more or less to the same extent as authors writing in English.

It has been suggested earlier (Kenny 2001: 70; Saldanha 2004) that research on features or norms of translation has tended to sideline exceptional or indeterminate cases rather than attempting to provide an integral account of the data and to integrate them into a more comprehensive model of translation behaviour. In some cases, studies designed to show evidence of normalization tendencies have shed light on what could be the individual translators' linguistic habits (Saldanha 2004; Olohan 2003). Translated texts may exhibit certain stylistic traits that cannot be explained solely by reference to the source text's style, linguistic constraints or potentially universal features of translation because they are actually a reflection of the translators' own individual preferences (see Baker 2000; Olohan 2003; Saldanha 2005; 2011a; 2011b). When these stylistic traits are consistent in the work of one translator they can be said to belong to the translator's style (Baker 2000; Saldanha 2005, 2011a; 2011b). Translator style is understood here to mean a coherent pattern of choices that 
is recognizable across a range of translations by the same translator, distinguishes that translator's work from that of others, and is 'motivated,' in the sense that it has a discernable function (Saldanha 2005; 2011b).

\section{Emphatic italics as features of the translator's style in the work of Margaret Jull Costa and Peter Bush}

This section presents a study of the use of emphatic italics in the work of two translators: Margaret Jull Costa and Peter Bush, with a view to exploring whether any patterns can be identified in the way each translator uses this typographic device. Margaret Jull Costa and Peter Bush were selected for a number of reasons, in particular, the number and wide range of authors they have translated and the similarities in their cultural and professional backgrounds. Given that the aim of the study was to find patterns that are typical of the work of one translator despite the specific constraints of source texts, it was important that the source texts within each corpus be as diverse as possible. The extent and diversity of the translators' output was also important because it was expected that the process of requesting permission for scanning the texts would significantly limit the number of texts that could be included in the corpus. Both Margaret Jull Costa and Peter Bush have translated Spanish and Portuguese texts from very diverse cultural backgrounds (Latin America and Europe), and in the case of Margaret Jull Costa, from different historical periods. As for the translators' own cultural and professional backgrounds, both are British and have lived in Great Britain for most of their adult lives. Neither of them has explicitly endorsed political agendas - such as feminist or minoritizing translation - in relation to their professional work. This means that differences in their style are unlikely to be due to different translation traditions or allegiances to different schools of thought. Finally, they are both highly acclaimed translators who have won prestigious awards for their translations, meaning that issues of quality were not likely to have a serious impact in the analysis.

\subsection{Corpora}

Two small corpora were compiled consisting of 5 translations by each translator, aligned with their source texts, written by five different authors. A complete list of the texts, their authors and translators is provided in Appendix 1. Copyright permission was requested for all texts. In the case of the corpus of translations by Margaret Jull Costa (MJC corpus), two of the source texts are in Portuguese and three are in Spanish. In the case of the corpus of translations by Peter Bush (PB corpus) one of the source texts is in Portuguese and four are in Spanish. Although all the translations in the corpora have been produced in the last two decades, the source texts are more varied in terms of date of publication. The earliest source text in the MJC corpus was published in 1880 and the more recent in 1993. In the PB corpus, the earliest source text was published in 1943 and the most recent in 1993. With the exception of Goytisolo's autobiography, Forbidden Territory, and of Paz's short story, The wolf, the Woods and the New Man (both in the PB corpus), all the other texts are novels or novellas. Given the interest in a unified 'authorial' effort and consistent style (Atkins, Clear et al. 1992: 2), it was decided that it would be important to have 
access to the full texts rather than extracts. Only minimal mark-up was added to the texts, consisting of SGML type tags for the following structural features: headings, notes and italics.

It would have arguably been desirable to have one or more source texts by the same author translated by more than one translator. Most studies of translator style tend to opt for this approach (see, for example, Malmkjær 2003; Winters 2004; 2007). Despite the obvious advantage of keeping the source text variable constant, this model has the disadvantage of being difficult to replicate, since retranslation is not actually a very common phenomenon. In contrast, the model used here can be replicated for almost any translator who has translated two or more different authors.

The results from COMPARA presented in the previous section were used for comparative purposes in this study. An ideal corpus for this purpose would have been a corpus of translations of Spanish and Portuguese narrative prose into English by many different translators, but this type of corpus was not readily available. The main problem with using COMPARA was that all the translations are from Portuguese, while only three of the ten translations in the PB and the MJC corpora are from that language. However, given that Spanish and Portuguese are closely related languages, and the results to be compared would be those for the English texts only, this was not thought to be enough of a drawback to dispense with a control corpus. Another difference to bear in mind is that the texts in COMPARA are extracts (30\% of the total number of words) and not full texts as in the MJC and the PB corpora, so the results had to be normalized. In other respects, COMPARA is a very good source of comparative data; it has the advantage of being freely accessible via the World Wide Web through an on-line concordancer, and occurrences of emphatic italics are tagged, so they are easily retrievable. Four of the translations in COMPARA are by Margaret Jull Costa, of which two are included in the MJC corpus in full, and one by Peter Bush. They were excluded from the analysis.

\subsection{Methodology}

Italics were tagged in the MJC and PB corpora, so searching for ' $<\mathrm{i}>^{*}$ ' retrieved all italics start tags followed by any other symbol. Occurrences of italics were classified according to the following criteria:

1) Author of the source text;

2) Whether the italics were:

2a) carried across from the source texts (i.e., appearing in source and target texts);

2b) omitted in the target text (i.e., they appear in the corresponding aligned units in the source text but not in the target text); or

2c) added in the target text, (i.e., appearing only in the target text);

3) Function for which italics were used.

The concordances were saved as a text file and converted into tables in Microsoft Excel spreadsheets. Cross-tabulation was then used in order to arrange the data in different ways so as to highlight the effect of each variable. As mentioned above, there are many other categories of italics apart from emphasis. In these two corpora, eleven other functional categories were identified. It goes without saying that the categorization was not without problems, and ultimately relied on the subjective interpretation of the researcher. Nevertheless, efforts were made to attempt to ensure reliability and 
replicability. The stability of the coding was tested by revising the codes at different stages over several months. Although some revisions entailed changes in the coding, these never affected more than a very small percentage of all cases. Reproducibility was tested only to a limited degree by having the classification examined by one independent person. Again, the resulting revisions were minimal, and this was considered sufficient as to whether the classification was reliable enough for tentative conclusions to be drawn. The contents of the corpora and the methodologies are described in more detail and the complete classification of concordances is available in Saldanha (2005).

In COMPARA, all occurrences of emphasis are tagged and it is possible to retrieve them using the online concordancer. However, upon close inspection, it became clear that the criteria applied in COMPARA for classifying emphatic italics was slightly different from the criteria applied in the PB and MJC corpora. For example, cases that were categorized as words mentioned rather than used in both corpora were categorized as emphasis in COMPARA (see example 7). ${ }^{6}$ Therefore, these occurrences had to be excluded.

(7) $[\ldots]$ he told me one day that he intended adding the title of philosopher and perhaps that of saint to his epitaph...

[...] ele me comunicou, certo dia, que tencionava acrescentar o título de filósofo, e talvez o de santo, ao seu epitáfio [...]

(de Carvalho 1995; translated by Rabassa 1999)

\subsection{Results and discussion}

TABLE 3

Emphatic italics in the PB, MJC and COMPARA corpora

\begin{tabular}{|l|c|c|c|c|}
\hline & \multicolumn{2}{|c|}{ COMPARA } & MJC & PB \\
\hline & $\begin{array}{c}\text { Non-translated } \\
\text { texts }\end{array}$ & $\begin{array}{c}\text { Translated } \\
\text { texts }\end{array}$ & $\begin{array}{c}\text { Translated } \\
\text { texts }\end{array}$ & $\begin{array}{c}\text { Translated } \\
\text { texts }\end{array}$ \\
\hline Number of words & 502,337 & 516,743 & 136,534 & 221,987 \\
\hline Number of texts & 21 & 29 & 5 & 5 \\
\hline Average number of words per text & 23,920 & 17,819 & 27,307 & 44,397 \\
\hline Number of texts with emphatic italics & 19 & 12 & 4 & 1 \\
\hline Total number of emphatic italics & 561 & 57 & 177 & 1 \\
\hline $\begin{array}{l}\text { Normalised number of emphatic } \\
\text { italics per 30,000 words }\end{array}$ & 33.5 & 3.3 & 38.9 & 0.1 \\
\hline
\end{tabular}

The frequency of emphatic italics in the $\mathrm{PB}$ corpus is closer to that calculated in the translated texts from COMPARA, while the frequency of emphatic italics in the MJC corpus is closer to the number of occurrences in non-translated English. However, these figures include emphatic italics in the translated texts that have been carried across from the source texts. In the MJC corpus, the overall number of italics is highly inflated by the number of occurrences in the translation of one text by de Sá-Carneiro. This author's particular use of emphatic italics also inflates the results presented earlier for non-translated Portuguese (Table 1). This is a case where the use of emphatic italics is a distinctive characteristic of the author's style or the particular text and therefore is not an accurate reflection of consistent translation patterns. A closer look at the distribution of emphatic italics in the MJC corpus clarifies this. 
Table 4 distinguishes between emphatic italics carried across from the source texts (138), italics omitted in the translation (34) and italics added in the translation (39). Within each of these categories, the frequencies for each file pair are reported separately. The number of occurrence is zero in cases where file pairs are not mentioned.

TABLE 4

Number of emphatic italics omitted, carried across and added in the MJC corpus

\begin{tabular}{|c|c|c|}
\hline & File pair & Total \\
\hline \multirow[t]{2}{*}{ Omitted } & de Queiroz's text & 2 \\
\hline & de Sá-Carneiro's text & 32 \\
\hline Total omitted & & 34 \\
\hline \multirow[t]{3}{*}{ Carried across } & de Queiroz's text & 4 \\
\hline & de Sá-Carneiro's text & 133 \\
\hline & Valenzuela's text & 1 \\
\hline \multicolumn{2}{|c|}{ Total carried across } & 138 \\
\hline \multirow[t]{4}{*}{ Added } & de Queiroz's text & 6 \\
\hline & de Sá-Carneiro’s text & 13 \\
\hline & Valenzuela's text & 16 \\
\hline & Valle Inclán's text & 4 \\
\hline Total added & & 39 \\
\hline
\end{tabular}

Margaret Jull Costa, as expected, tends to reproduce the italics used for emphasis in the ST. Only $20 \%$ of all emphatic italics in the source texts (34 occurrences) have been omitted. Most of the 177 occurrences in the target texts have been carried across from the source text. However, these occurrences are not evenly distributed between the texts: approximately $96 \%$ of the occurrences belong to the text by de Sá-Carneiro and its translation. Added italics (39 occurrences) represent a considerably lower percentage (22\%) of all emphatic italics in the target texts. Nevertheless, the added italics are clearly not used to compensate for the omitted italics: while the addition of italics is a recurrent phenomenon in 4 of the 5 translations, 32 of the 34 omissions are concentrated in one file pair. Overall, the most consistent pattern in Margaret Jull Costa's translations is the addition of typographical emphasis where there is none in the source texts. This is in stark contrast to what Peter Bush tends to do: in the PB corpus, there is only one occurrence of italics for emphasis in the translations and this occurrence is carried across from the source text (Buarque's Estorvo).

Another interesting fact to note in the MJC corpus is that 38 of the 39 occurrences of italics added in the translated texts mark information focus, whereas the emphasis created by the italics in the source texts is predominantly of a different kind (see example 5 above). Therefore, there is a clear distinction in terms of the function of the emphatic italics carried across from the source texts and those that appear in the translation only.

Table 5 presents results for italics that have been added in the translated texts across the three corpora. The differences in this table are less pronounced than in Table 3, but the normalized frequency of added emphatic italics in the MJC corpus is still five times higher than in COMPARA translations. 
TABLE 5

Added emphatic italics in COMPARA, MJC and PB corpora

\begin{tabular}{|l|c|c|c|}
\hline & COMPARA & MJC & PB \\
\hline Number of words & 516,743 & 136,534 & 221,987 \\
\hline Total number of added emphatic italics & 30 & 39 & 0 \\
\hline $\begin{array}{l}\text { Normalised number of added emphatic } \\
\text { italics per 30,000 words }\end{array}$ & 1.7 & 8.6 & 0 \\
\hline
\end{tabular}

It is also important to check whether there is anything other than emphatic italics in the source texts that would explain the use of emphatic italics in those target texts where they are added. One possible explanation would be that they are triggered by the use of other focus markers in the source texts (see examples 3 and 4 above). However, in COMPARA, of the 30 occurrences of added information focus in translated texts, only 5 could be said to have been triggered by the use of focusing devices in Portuguese. In the MJC corpus, of 39 occurrences of italics marking information focus, only 12 could be said to have been triggered by a marked information structure in the ST. In most cases, as in example 8 below, the marked information focus cannot be said to be compensating for source text elements that cannot be replicated in a more literal manner. This translation is indeed quite literal, with the exception of the shift in information focus in the first clause.

(8) [...] eu era o meu drama - a coisa artificial - e o meu drama a realidade.

[I was my play - the artificial thing - and my play reality.]

[...] I was my play - that is, the artificial thing - and my play was real.

(de Sá-Carneiro 1914; translated by Jull Costa 1993)

In some cases, it could be argued that the use of marked information focus follows considerations that are related to the socio-textual conventions of the two linguistic systems, as in example 9. Here the translation is not literal: an imperative is transformed into a suggestion using the modal 'can,' probably due to different rules of politeness in the source and target text languages. The Portuguese can be read as a polite, if assertive, suggestion, but if it were to be translated literally into English as 'do something,' it would likely be interpreted as a suggestion with an implicit criticism, namely that the addressee is not doing enough. The use of emphatic italics could be said to strengthen the force of the suggestion, as a way of compensating for the loss of assertiveness with the use of 'can.'

(9) - Faça uma coisa. Procure a família de Ti Chin-Fu.

[Do something. Search for Ti Chin-Fu's family.]

"What you can do is find Ti Chin-Fu's family."

(de Queiroz 1880; translated by Jull Costa 1993)

Even taking cases such as this one into account, it is clear that there is no direct correspondence between marked information focus in the ST and use of emphatic italics marking information focus in the TT. In other words, Margaret Jull Costa's use of emphatic italics in her translations to mark information focus seems to be a stylistic preference that distinguishes her work from that of other translators.

The fact that the translator leaves an imprint of her own style on the text does not mean that her style will supersede the author's . It is likely that even those stylistic choices that cannot be explained solely as a replication of the source text's style 
will nevertheless be used by the translator in such a way as to work together with the author's stylistic choices to create a coherent stylistic effect. One text in the MJC corpus, Industrias y andanzas de Alfanhuí, by Sánchez Ferlosio, does not include any occurrences of emphatic italics, either in its source or target versions. A possible explanation for this exception lies in the different narrative style of this novel compared to other novels in the MJC corpus. Because they are associated with a prosodic feature, the effect of emphatic italics is reminiscent of spoken language. As a consequence, this function is generally associated with a more informal and involved tone of language. Two of the texts in the MJC corpus, those authored by de Queiroz and by de Sá-Carneiro, are narrated in the first person. They both relate very disturbing personal experiences, described from a subjective point of view in a highly involved tone. In these cases, the emphatic italics bring forward the echo of the narrator's voice, establishing a more informal, conversational tone that brings the narrator closer to the reader (see example 8 above). Industrias $y$ andanzas de Alfanhuí, on the other hand, is narrated in the third person and the style is considerably more detached. Although the fictional world is presented through the eyes of the main character, the descriptive focus is on matters external to the character, with only brief glimpses into the character's inner world. The two other texts in the MJC corpus, authored by Valenzuela and del Valle-Inclán, are also narrated in the third person, but they differ from Sánchez Ferlosio's in that they include comparatively much more dialogue and this is where the emphatic italics are used (see example 10 below). In the translation of the text by del Valle-Inclán, where all the italics are added (rather than carried across from the source texts), they always appear in conversations. In the text by Valenzuela, where all but one of the emphatic italics are added, $76.5 \%$ of the occurrences of italics appear in dialogues.

(10) - Xavier, tienes que ver su última obra: ¡El Paso de las Caídas! ["Xavier, you have to see his latest work: El Paso de las Caídas!»]

"Xavier, you must see his latest work: The Fallen."

(del Valle-Inclán 1933; translated by Jull Costa 1997)

Example 10 is another case where there is marked information focus in the target text but not in the source text. The main reason for using italics seems to be to convey enthusiasm and assertiveness, and this involves shifting the focus from where it is in the source text, the name of the play, to the illocutionary function of the utterance, highlighted by the modal.

The control corpus, COMPARA, contains extracts of two translations by Margaret Jull Costa that are not included in the MJC corpus: The Relic and The Great Shadow (by de Queiroz 1880 and de Sá-Carneiro 1914, respectively). The same patterns described above for the use of italics in the MJC corpus are reproduced in these two novels. The Great Shadow has one occurrence while The Relic has 9 occurrences of added italics marking information focus. In other novels translated by Margaret Jull Costa, including translations of books by the Brazilian writer Paulo Coelho, italics are also common, although a close comparison with source texts was not carried out. On the other hand, in The Double, the translation of a novel by José Saramago, no italics are used. The Double, like Industrias y andanzas de Alfanhui, is also narrated in the third person and the narrator takes an even more detached and objective perspective on the fictional world being presented. In addition, Saramago's 
style involves a very minimal use of typographical devices. He does not use quotation marks or even periods in dialogues, and uses full stops only rarely. This results in very long and plain-looking paragraphs. The addition of italics in such a text would clearly disrupt the effect created by the author's choices. Still, the fact that the translator's stylistic choices are in tune with the narrative style of the source texts should not be taken to mean that the source text style determines the choice of stylistic features in the target text.

Saldanha $(2005 ; 2011 \mathrm{a} ; 2011 \mathrm{~b})$ argues that stylistic traits that are consistent across the works of one translator do not reproduce the source text's stylistic features and cannot be explained as a result of linguistic constraints, can sometimes be considered features of the translator's style. However, for recurrent linguistic features to be considered distinctive stylistic markers in a translator's work, they should form a coherent pattern of choice together with other stylistic features, and they should be motivated, in the sense that they perform a discernable function. The requirements of coherence and motivation are worth highlighting because they prevent us from making easy generalizations, for example about the tendency of translators towards conservatism or explicitation. It is not possible to go into detail here about other recurrent linguistic patterns in Margaret Jull Costa's and Peter Bush's translation (see Saldanha 2005, 2011a, 2011b); however, it is important to discuss the potential motivations explored in that study, particularly in reference to emphatic italics.

In interviews conducted with the two translators, they were asked about reasons for the use or absence of italics in their translations. Peter Bush replied that he doesn't "really like using italics for emphasis," that he tries to "bring in the emphasis using other forms of emphasis." Although, at first sight, he seems to conform to style guide recommendations, when this preference is considered in conjunction with other recurrent linguistic choices in his translations, such as the relatively frequent use of lexical borrowings, it is difficult to see them as indicative of a conservative use of language. Apart from the systematic examination of the works included in the corpus, other translations by Peter Bush were examined in order to confirm that the avoidance of emphatic italics was indeed a consistent trait of his work. Interestingly enough, after this study was carried out and after the interview was conducted (he had access to both the results of the study and a summary of the interview), he published a translation where he does use italics to mark information focus. It is not possible to venture any explanations without a more in-depth investigation, but it is worth noting that the book in question, A Not So Perfect Crime, by the Catalan writer Teresa Solana, is one of the few detective novels Bush has translated, and one that is written in a far more colloquial style than, for instance, the detective stories by Leonardo Padura, which have also recently been added to the long list of his translations.

Margaret Jull Costa is aware that style guides discourage the use of italics for purposes of emphasis, although she does not seem too concerned about their advice, she is more concerned about how the translation adapts to the rhythm of English. She refers to spoken language and "the rhythm of English, where certain words are emphasised" and mentions that she often reads the novel aloud to get the rhythm right. ${ }^{8}$ She tries to avoid emphatic italics by structuring the sentence in such a way that the structure itself marks where the emphasis should fall, but "sometimes it is not possible, and if it's important that the reader knows if it's this way or that way, I will use them" (emphasis is mine). It is clear that Jull Costa is aware that italics can 
guide interpretation and that she exploits this resource, but her main motivation seems to be to convey intonation patterns. In her writings, Jull Costa expresses a clear desire for her translations to read and sound as natural as if they had been conceived in English (Jull Costa 1999: 182); she wants readers to stop thinking that translations are not worth reading because they are not 'the real thing.' It is quite likely that the use of emphatic italics to highlight prosodic patterns is a strategy to achieve this particularly English flow to the reading experience.

\section{Conclusion}

This article has presented a theoretical argument and empirical evidence for a new understanding of how information focus is realized in written English texts and has demonstrated that rather than a confession of stylistic failure, italics are a useful stylistic device that can be used in English to mark new information by signaling typographically the tonic accent that is used in spoken English to mark information focus. The article has also presented an overview of contrastive work exploring the use of italics in translation. It was noted that Romance languages tend to use other devices to mark information focus, and data from a bidirectional parallel EnglishPortuguese corpus suggest that emphatic italics are not generally used for that purpose in Portuguese. The data presented here also suggest that emphatic italics marking information focus are not as common in literary translations from Portuguese as in non-translated English texts. More extensive research using other text-types and translations from other languages are required to determine whether the relative lower frequency of emphatic italics is indeed a more common feature of translated English than of non-translated English. In this regard, the article also offers an exploration of the compatibility between predictions made by hypotheses concerning general features of translation and highlights the potential risks of quick generalizations in terms of general features without taking into account individual preferences.

A systematic investigation of the use of italics in the work of two translators working from Spanish and Portuguese into English shows that consistent and distinctive patterns can be found in their use of emphatic italics: Peter Bush consistently avoids them and Margaret Jull Costa often uses them in places where they are not used in the source text. These italics generally mark information focus but, contrary to what may be expected, they are not used to compensate for marked information focus using other means in the source texts. A qualitative analysis of added italics in Jull Costa's translations, supported with data from an interview with the translator, suggests that italics are used to facilitate interpretation and increase fluency and idiomaticity. The distinction between new and given information, which emphatic italics highlight, belongs to the textual function of language. It is a distinction that allows for the organization of the text in a way that it is coherent and understandable. Therefore, the addition of emphatic italics results in a higher degree of explicitness on the textual level. Moreover, because of their association with spoken and, in particular, conversational language, they can have an effect upon the level of formality and involvement the text conveys. From a cross-linguistic perspective, bearing in mind that Spanish and Portuguese do not rely as much as English on prosodic patterns for highlighting information focus, the addition of italics can be seen as an effort to produce an idiomatic and fluent text. 


\section{NOTES}

1. See El PAís (2009): Libro de estilo. Madrid: Ediciones El País.

2. Italics come from the original texts. Where appropriate, underlines have been added to highlight the lexical items that are discussed and glosses have been provided.

3. This example is taken from a text in the COMPARA corpus:

Dourado, Autran (1975): Os Sinos da Agonia. Rio de Janeiro: Editora Expressão e Cultura. Dourado, Autran (1988): The Bells of Agony. (Translated by John Parker). London: Peter Owen.

4. COMPARA is an ongoing project (see http://www.linguateca.pt/COMPARA/compara_en.html, visited on 31 March 2010). The results presented here were obtained from the 2005 version of the corpus.

5. This is the average length of the texts in the three corpora used here.

6. This example is taken from a text in the COMPARA corpus: de Carvalho, Mário (1995): Um deus passeando pela brisa da tarde. Lisbon: Caminho. de Carvalho, Mário (1999): A god strolling in the cool of the evening. (Translated by Gregory Rabassa). London: Phoenix.

7. Interview of Peter Bush by Gabriela Saldanha (2004).

8. Interview of Margaret Jull Costa by Gabriela SAldanha (2004).

\section{REFERENCES}

Atrins, Sue, Clear, Jeremy and Olster, Nicholas (1992): Corpus Design Criteria. Literary and Linguistic Computing. 7(1):1-16.

BAKER, Mona (1993): Corpus Linguistics and Translation Studies: Implications and applications. In: Mona Baker, Gill Francis and Elena Tognini-Bonelli, eds. Text and Technology. Amsterdam and Philadelphia: John Benjamins, 233-250.

BAKer, Mona (1995): Corpora in Translation Studies: An Overview and Some Suggestions for Future Research. Target. 7(2):223-243.

BAKer, Mona (1996): Corpus-based Translation Studies: The Challenges that Lie Ahead. In: Harold Somers, ed. Terminology, LSP and Translation: Studies in Language Engineering in honour of Juan C. Sager. Amsterdam and Philadelphia: John Benjamins, 175-186.

BAKER, Mona (2000): Towards a Methodology for Investigating the Style of a Literary Translator. Target. 12(2):241-266.

Burchifeld, Robert W. (1996): Fowler's Modern English Usage. Oxford: Clarendon Press.

BUtLeR, Christopher S. (2005): Focusing on focus: A comparison of Functional Grammar, Role and Reference Grammar and Systemic Functional Grammar. Language Sciences. 27(6):585-618.

Cruttenden, Alan (1997): Intonation. Cambridge: Cambridge University Press.

Crystal, David (1998): Towards a typographical linguistics. Type. 2(1):7-23.

Douglas, Peter (2009): Encoding intonation: The use of italics and the challenges for translation. In: Michaela Mahlberg, Victorina González-Díaz and Catherine Smith, eds. Proceedings of the Corpus Linguistics Conference (CL2009) (Liverpool, 20-23 July 2009). Visited 12 May 2011, <http://ucrel.lancs.ac.uk/publications/cl2009/>.

Fowler, Henry Watson (1965): A Dictionary of Modern English Usage. Oxford: Clarendon Press.

Frankenberg-Garcia, Ana and Santos, Diana (2003): Introducing COMPARA: the Portuguese-English Parallel Corpus. In: Federico Zanettin, Silvia Bernardini and Dominique STEWART, eds. Corpora in Translator Education. Manchester: St. Jerome, 71-87.

Halliday, M.A.K. (1967): Notes on transitivity and theme in English: Part 2. Journal of Linguistics. 3(2):199-244.

Hervey, Sándor and Higgins, Ian (2002): Thinking French Translation. London and New York: Routledge.

Jull Costa, Margaret (1999): On Translation and on Translating Saramago in Particular. Portuguese Studies. 15:207-215.

Kenny, Dorothy (2001): Lexis and Creativity in Translation: A Corpus-based Study. Manchester: St. Jerome. 
López Folgado, Vicente (2000): The Role of Italics in Translation: A Pragmatic View. In: María Pilar Navarro Errasti, Rosa Lorés Sans, Silvia Murillo Ornat, et al., eds. Transcultural Communication: Pragmalinguistic Aspects. Zaragoza: Anubar Ediciones, 91-98.

MaLmкjÆR, Kirsten (2003): What happened to God and the angels: an exercise in translational stylistics. Target. 15(1):37-58.

Martínez Caro, Elena (1995): Variación sintáctica en español como expresión pragmática de foco. Estudios de Lingüistica Aplicada. 21/22:91-109.

Martínez Caro, Elena (1999): Gramática del Discurso: Foco y Énfasis en Inglés y en Español. Barcelona: Promociones y Publicaciones Universitarias.

Martins, Eduardo (2003): Manual de Redação e Estilo. São Paulo: O Estado de São Paulo.

Mcateer, Erica (1990): Typeface Emphasis and Information Focus in Written Language. Applied Cognitive Psychology. 6(4):354-359.

NorRICK, Neal (2000): Conversational Narrative: Storytelling in Everyday Talk. Amsterdam and Philadephia: John Benjamins.

Olohan, Maeve (2003): How frequent are the contractions? A study of contracted forms in the Translational English Corpus. Target. 15(1):59-89.

SAldanha, Gabriela (2004): Accounting for the Exception to the Norm: a Study of Split Infinitives in Translated English. Language Matters: Studies in the Languages of Africa. 35(1):39-53.

Saldanha, Gabriela (2005): Style of Translation: An exploration of stylistic patterns in the translations of Margaret Jull Costa and Peter Bush. Doctoral thesis unpublished. Dublin: Dublin City University.

SAldanha, Gabriela (2011a): Style of translation: the use of foreign words in translations by Margaret Jull Costa and Peter Bush. In: Alet Kruger, Kim Wallmach and Jeremey Munday, eds. Corpus Based Translation Studies: Research and Applications. London and New York: Continuum, 237-258.

SALDAnHA, Gabriela (2011b): Style of translation: methodological considerations. The Translator. 17(1): 25-50.

Schopp, Jürgen F. (1996): The Typographic Competence of the Translator: Visual Text Design and Desktop Publishing. In: Proceedings of the XIV FIT World Congress. Melbourne: Australia, 189-193.

Schopp, Jürgen F. (2002): Typography and Layout as a Translation Problem. In: Proceedings of the XVI FIT World Congress. Vancouver, Canada, 189-193.

Slancarova, Dana (1998): On the Use of Italics in English and Czech. Master thesis unpublished, Brno: Masaryk University. Visited 7 June 2010, <http://www.phil.muni.cz/angl/DIPLOMKY/ 1998/slancarova/ds_ch0.htm>.

Swerts, Mark, Krahmer, Emiel and Avesani, Cinzia (2002): Prosodic Marking of Information Status in Dutch and Italian: A comparative analysis. Journal of Phonetics. 30(4):629-654.

TirkKonen-Condit, Sonja (2004): Unique items - over- or under-represented in translated language? In: Anna Mauranen and Pekka Kujamäki, eds. Translation Universals. Do they exist? Amsterdam and Philadephia: John Benjamins, 177-184.

Truss, Lynne (2003): Eats, Shoots \& Leaves: The Zero Tolerance Approach to Punctuation. London: Profile Books.

VAllduví, Enric and Engdahl, Elisabet (1996): The English realisation of information packaging. Linguistics. 34(4): 459-519.

Vanderaumera, Ria (1985): Dutch Novels Translated into English: The Transformation of a "Minority" Literature. Amsterdam: Ropopi.

Walker, Sue (2001): Typography and Language in Everyday Life: Prescriptions and Practices. London: Longman.

Winters, Marion (2004): F. Scott Fitzgerald's Die Schönen und Verdammten: A corpus-based study of loan words and code switches as features of translators' style. Language Matters: Studies in the Languages of Africa. 35(1):248-258.

Winters, Marion (2007): F. Scott Fitzgerald's Die Schönen und Verdammten: A Corpus-based Study of Speech-act Report Verbs as a Feature of Translators' Style. Meta. 52(3):412-425. 


\section{APPENDIX}

Corpora of works and their translations by Peter Brush (PB corpus) and Margaret Jull Costa (MJC corpus)

\section{PB corpus}

Buarque, Chico (1991): Estorvo. São Paulo: Companhia das Letras.

Buarque, Chico (1992): Turbulence. (Translated by Peter Bush). New York: Pantheon.

Goytisolo, Juan (1985): Coto Vedado. Madrid: Alianza Editorial.

Goytisolo, Juan (1989): Forbidden Territory: The Memoirs of Juan Goytisolo 1931-1956. (Translated by Peter Bush). London: Quartet Books.

Onetti, Juan Carlos (1943): Para esta noche. Montevideo: Arca.

Onetti, Juan Carlos (1991): Tonight. (Translated by Peter Bush). London: Quartet Books.

PAz, Senel (1991): El lobo, el bosque y el hombre nuevo. Mexico: Ediciones Era.

Paz, Senel (1995): The Wolf, the Woods and the New Man. (Translated by Peter BusH). London: Bloomsbury.

SEPÚlVEDA, Luis (1993): Un viejo que leía novelas de amor. Barcelona: Tusquets Editores.

Sepúlveda, Luis (1993): The Old Man Who Read Love Stories. (Translated by Peter Bush). London: Souvenir Press.

\section{MJC corpus}

DE Queiroz, Eça (1880): O Mandarim. Porto: Livraria Chardron.

DE Queiroz, Eça (1993): The Mandarin. (Translated by Margaret Jull Costa). Sawtry: Dedalus Books.

De SÁ-Carneiro, Mário (1914): A confissão de Lúcio. Lisbon: Assírio \& Alvim.

de SÁ-Carneiro, Mário (1993): Lúcio’s Confession. (Translated by Margaret Jull Costa). Sawtry: Dedalus Books.

Sánchez Ferlosio, Rafael (1961): Industrias y andanzas de Alfanhuí. Madrid: Destino.

SÁnchez Ferlosio, Rafael (2000): Adventures of the Ingenious Alfanhui. (Translated by Margaret Jull Costa). Sawtry: Dedalus Books.

Valenzuela, Luisa (1993): Realidad nacional desde la cama. Buenos Aires: Grupo Editor Latinoamericano.

Valenzuela, Luisa (1995): Bedside Manners. (Translated by Margaret Jull Costa). London: Serpent's Tail.

del Valle-Inclán, Ramón (1933): Sonata de Primavera. Madrid: España.

Del Valle-Inclán, Ramón (1997): Spring Sonata. (Translated by Margaret Jull Costa). Sawtry: Dedalus Books. 